\title{
Oral cancer trends in a single head-and-neck cancer center in the Netherlands; decline in T-stage at the time of admission
}

\author{
Manon Weijers ${ }^{1}$, C.René Leemans ${ }^{2}$, Irene H. Aartman ${ }^{3}$, K.Hakki Karagozoglu ${ }^{1}$, Isaäc van der Waal ${ }^{1}$
}

\author{
${ }^{1}$ Department of Oral and Maxillofacial Surgery/Pathology, VU University Medical Center (VUmc)/Academic Centre for Den- \\ tistry (ACTA), Amsterdam, The Netherlands \\ ${ }^{2}$ Department of Otolaryngology Head and Neck Surgery, VU University Medical Center (VUmc), Amsterdam, The Netherlands \\ ${ }^{3}$ Department of Social Dentistry, Academic Centre for Dentistry Amsterdam (ACTA), Amsterdam, The Netherlands
}

Correspondence:

VUmc/ACTA

Department of Oral and Maxillofacial Surgery/Pathology, P.O. Box 7057 ,

1007 MB Amsterdam.

The Netherlands,

i.vanderwaal@vumc.nl

Received: 03/08/2011

Accepted: 19/08/2011
Weijers M, Leemans CR, Aartman IH, Karagozoglu KH, van der Waal I. Oral cancer trends in a single head-and-neck cancer center in the Netherlands; decline in T-stage at the time of admission. Med Oral Patol Oral Cir Bucal. 2011 Nov 1;16 (7):e914-8.

http://www.medicinaoral.com/medoralfree01/v16i7/medoralv16i7p914.pdf

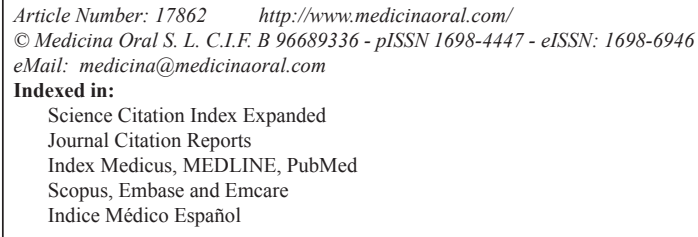

\begin{abstract}
Objectives: In this study we evaluated the possible epidemiologic changes of oral cancer patients in the Netherlands between the years 1980-1984 and 2000-2004. We specifically studied the differences in male-female ratio, age, TNM-stage, site distribution, and alcohol and tobacco use. Materials and Methods: Patients from the VU University Medical Center with an oral squamous cell carcinoma of the oral cavity registered in 1980-1984 ( $\mathrm{n}=200$ ), group 1, were compared to patients registered in 2000-2004 ( $\mathrm{n}=184)$, group 2. Trends in prevalence, site distribution, TNM-stage, alcohol and tobacco use, age and gender were studied. Results: The male-female ratio has decreased from 1.8 to 1.2. There were no differences in age between the two groups of patients. The site distribution was similar in both groups. The most commonly involved sites were the tongue and the floor of mouth. In group 2 more patients were diagnosed with a T1 tumour. There were no differences in tobacco use between the two different groups. There were much more light drinkers (0-2 drinks per day) in group 2 than in group 1, whereas there were more heavy drinkers ( $>4$ per day) in group 1 than in group $2(\mathrm{p}<0.001)$. This was observed in both male and female patients. Conclusion: In our study there were no significant differences between the patients registered in the years 1980-1984 and 2000-2004 regarding the mean age of the patients, site distribution and smoking habits. The male-female ratio has decreased. In the recent group more patients were staged T1N0 and there was a strong decrease of the patients who were heavy drinkers.
\end{abstract}

Key words: Oral cancer, squamous cell carcinoma, epidemiology. 


\section{Introduction}

Squamous cell carcinoma makes up approximately $90 \%$ of oral cancers, the remaining $10 \%$ consisting of malignant salivary gland tumours of the accessory glands, melanoma, sarcomas of the soft tissues and the jaw bones, malignant odontogenic tumours, non-Hodgkin lymphomas and metastases from primary tumours located elsewhere in the body. The main etiologic factors of oral squamous cell carcinoma (OSCC) are tobacco and alcohol use (1-3). Human papilloma virus, particular type 16, may play an etiologic role in a small subset of patients (4).

In the past decade several studies have been published that showed an increase in the incidence of OSCC and, at the same time, a tendency to occur more often in the age group below the age of 40 years. In the present study the possible epidemiologic changes of oral cancer patients treated at the VU University Medical Center, Amsterdam, have been examined comparing the periods 1980-1984 and 2000-2004. We specifically studied the possible differences in male-female ratio, age, subsite distribution, TNM-stage, and alcohol and tobacco use.

\section{Material and Methods}

Patients were drawn from the oral cancer database of the VU University Medical Center, Amsterdam, the Ne- therlands. In this study only patients with squamous cell carcinoma of the oral cavity were included (ICD 10 141, 143-145).

The data of patients registered in the period 1980-1984 were compared to those of patients registered in the period 2000-2004. For the statistical analysis chi-square tests were used and an independent sample t-test for the difference between the groups regarding age. A $p$ value $<0.05$ was considered as statistical significant.

\section{Results}

In the period 1980-1984 (group 1) a total number of 200 patients with an oral squamous cell carcinoma was registered, while that number was 184 in the period 20002004 (group 2).

Gender and age are summarized in (Table 1). ICD codes and subsites are depicted in (Table 2). Clinical $\mathrm{T}$ and $\mathrm{N}$ stages are depicted in (Table 3), while the data about smoking habits and the use of alcohol are summarised in (Tables 4 and 5), respectively.

The male-female ratio in group 1 was 1.8: 1 and this ratio was 1.2: 1 in group 2 . There were no significant differences in age between the two groups of patients. No increase of patients under the age of 40 years was observed. The distribution of the oral subsite of the tumours as indicated in (Table 2) showed no change either. The most common subsites were the lateral borders of the tongue and the floor of mouth.

Table 1. Demographic data.

\begin{tabular}{|l|c|c|c|}
\hline & $\begin{array}{c}\text { Group 1 (1980-1984) } \\
\mathbf{n = 2 0 0}\end{array}$ & $\begin{array}{c}\text { Group 2 (2000-2004) } \\
\mathbf{n = 1 8 4}\end{array}$ & $\begin{array}{c}\text { P } \\
\text { value }\end{array}$ \\
\hline Male & $129(64.5 \%)$ & $102(55.4 \%)$ & \\
\hline Female & $71(35.5 \%)$ & $82(44.6 \%)$ & 0.070 \\
\hline Mean age (SD) & $64.06(13.0)$ & $62.5(12.7)$ & 0.238 \\
\hline Number of patients below 40 years & 10 & 8 & 0.763 \\
\hline
\end{tabular}

Note: no statistically significant differences were observed between the two periods.

Table 2. Localisation of oral squamous cell carcinoma.

\begin{tabular}{|l|c|c|}
\hline \multicolumn{1}{|c|}{ Oral subsite } & $\begin{array}{c}\text { Group 1 (1980-1984) } \\
\mathbf{n = 2 0 0}\end{array}$ & $\begin{array}{c}\text { Group 2 (2000-2004) } \\
\mathbf{n = 1 8 4}\end{array}$ \\
\hline Lower lip $(\mathrm{C} 00.1,2,4,5,8,9)$ & 14 & 17 \\
\hline Tongue $(\mathrm{C} 02.0,1,2,3,8,9)$ & 57 & 58 \\
\hline Gingiva maxilla $(\mathrm{C} 03.0)$ & 10 & 26 \\
\hline Gingiva mandible $(\mathrm{CO} 3.1)$ & 40 & 51 \\
\hline Floor of mouth $(\mathrm{C} 04.0,1,8,9)$ & 62 & 9 \\
\hline Cheek $(\mathrm{C} 06.0)$ & 7 & 2 \\
\hline Palate $(\mathrm{C} 05.0,1,9)$ & 5 & 2 \\
\hline Multifocal $(\mathrm{C} 06.8)$ & 2 & 15 \\
\hline Other & 3 & $\mathbf{2}$ \\
\hline
\end{tabular}

Note: no statistically significant differences were observed between the two periods. 
Table 3. T-stage, N-stage and T1N0.

\begin{tabular}{|l|c|c|}
\hline T-stage & $\begin{array}{c}\text { Group 1 (1980-1984) } \\
\mathbf{n = 2 0 0}\end{array}$ & $\begin{array}{c}\text { Group 2 (2000-2004) } \\
\mathbf{n = 1 8 4}\end{array}$ \\
\hline T1 & 48 & $69^{*}$ \\
\hline T2 & 84 & 60 \\
\hline T3 & 48 & 32 \\
\hline T4 & 20 & 23 \\
\hline N-stage & & \\
\hline N0 & 124 & $148^{* *}$ \\
\hline N1 & 55 & 22 \\
\hline N2 & 15 & 14 \\
\hline N3 & 6 & - \\
\hline T1N0 & 45 & $66^{* * *}$ \\
\hline
\end{tabular}

* There is a significant higher number of patients with T1 in group 2 $(\mathrm{p}=0.015)$

** There is a significant increase in patients with $\mathrm{N} 0$-stage in group 2 $(\mathrm{p}<0.001)$

*** There is a significant increase in patients with T1N0-stage in group $2(\mathrm{p}=0.032)$

Table 4. Smoking habits.

\begin{tabular}{|l|c|c|c|c|c|c|}
\hline \multirow{2}{*}{ Smoking habits } & \multicolumn{3}{|c|}{ Group 1 (1980-1984) } & \multicolumn{3}{c|}{ Group 2 (2000-2004) } \\
\cline { 2 - 7 } & Total & Men & Women & Total & Men & Women \\
\hline Non-smoker & 58 & 22 & 36 & 62 & 27 & 35 \\
\hline$<10$ sig/day & 10 & 7 & 3 & 5 & 3 & 2 \\
\hline $10-20$ sig/day & 38 & 33 & 5 & 22 & 17 & 5 \\
\hline$>20$ sig/day & 82 & 61 & 21 & 67 & 38 & 29 \\
\hline Not registered & 12 & & & 28 & & \\
\hline Total & 188 & 123 & 65 & 156 & 85 & 71 \\
\hline
\end{tabular}

Note: no statistically significant differences in smoking habits among men (p 0.120) and women $(\mathrm{p}=0.745)$ in the two periods.

Table 5. Alcohol use.

\begin{tabular}{|l|c|c|c|c|c|c|}
\hline \multirow{2}{*}{ Alcohol use } & \multicolumn{3}{|c|}{ Group 1 (1980-1984) } & \multicolumn{3}{c|}{ Group 2 (2000-2004) } \\
\cline { 2 - 7 } & Total & Men & Women & Total & Men & Women \\
\hline None & 44 & 18 & 26 & 23 & 9 & 14 \\
\hline 0-2 per day & 32 & 16 & 16 & 60 & 31 & 29 \\
\hline 2-4 per day & 49 & 41 & 8 & 37 & 22 & 15 \\
\hline$>4$ per day & 59 & 45 & 14 & 27 & 19 & 8 \\
\hline Not registered & 16 & 9 & 7 & 37 & 21 & 16 \\
\hline Total & 184 & 120 & 64 & 147 & 81 & 66 \\
\hline
\end{tabular}

Note: there were statistically significant more light drinkers (0-2 per day) in the second period, both in men $(\mathrm{p}=0.001)$ and in women $(\mathrm{p}=0.011)$ 
The T-stage is visualized in (Table 3). There are more patients in group 2 with T1 stage (p 0.015) compared to the patients from the first group. The $\mathrm{N}$-stage is shown in (Table 4). There are significantly more patients in the group 2 with a lower $\mathrm{N}$-stage $(\mathrm{p}<0.001)$ than in the first group.

There were no statistically significant differences in tobacco use in both men and women between the two periods. With regard to the use of alcohol a statistical difference was found: there were more light drinkers in the category 0-2 drinks per day in group 2 than in group 1 , whereas there were more heavy drinkers ( $>4$ per day) in group 1 than in group $2(p<0.001)$. This was found in both male and female patients.

\section{Discussion}

In the majority of the literature an increase of patients with oral cancer was observed in the past decades. Warnakulasuriya et al. stated that in the last two decades there was an increase of both oral and oropharyngeal cancer in Western Europe (5). Karim-Kos et al. found an increase of smoking-related cancers in whole Europe (6). Curado et al. comparing data from 1998 and 2002 found an increase in incidence in oral cancer for both men and women for North and East Europe and a stable incidence in the West of Europe (7). However, it seems somewhat questionable to compare data obtained from two periods with an interval of just four years. On the other hand, a decrease in the age-standardized incidence of oral squamous cell carcinoma in the last three decades in the U.S. has been reported (8). In a recent European study it was noted that oral cancer mortality has started to decline in generations born after the 1950 's (9). Since there was no formal cancer registry in the Netherlands yet in the first period (1980-1984) no reliable information is available about a possible increase of oral cancer in the Netherlands when comparing the period 1980-1984 and the period 2000-2004. Braakhuis et al. reported a stable incidence in the Netherlands for oral cancer in men and an increasing incidence in women over the years 1989-2006 (10).

The male-female ratio decreased in the present study. This is also seen in other studies (6). Apparently, this decrease was not related to a decrease of smoking habits among men nor an increase of smoking in women as will be discussed later.

In our study no change in the mean age of the patients was observed. The number of patients below 40 years of age remained stable. This is in accordance with the study by Müller et al. who observed a more than fourfold increase of patients below 40 years of age in the period between 1974 and the late 1980's and then remaining stable thereafter until 2006 (11). In a few studies, amongst others from Scotland and Ireland, an increasing incidence of oral cancer in young patients has been reported $(12,13)$. No convincing explanation could be provided for that finding (14).

No differences between our two groups of patients were seen with regard to site distribution. The most common sites were the lateral borders of the tongue and the floor of mouth. This is in accordance with the literatura (1518).

In this study a clear difference between the two groups concerning T1- and N0- stages was seen. Remarkably, there were more patients diagnosed with $\mathrm{T} 1$ tumours in the 2000-2004 period. This suggests that patients with oral cancer are diagnosed in an earlier stage. Perhaps, this is caused by improved education of the public or increased awareness among dental and medical practitioners. In a study from an other head and neck cancer center in the Netherlands an increase in the percentage of patients with T4 oral cancers was observed, being $22,7 \%$ in the $1985-1989$ period and $32,9 \%$ in the $1995-$ 1998 period (19), while in the present study this percentage has only slightly increased in the two studied periods $(10,0 \%$ and $12,5 \%$ respectively, being statistically not significantly different).

In the study by Hoffman et al. the distribution of stages remained stable when comparing the years 1985-1989 and 1990-1994 in the US (20). However, in that study no distinction was made between cancer of the oral cavity and other head and neck cancers. Interestingly, in the present study in 2000-2004 more patients were classified with N0 stage of the neck. In the early 90's the ultrasound guided fine needle aspiration was introduced for the staging process of the neck, which would result in a lower number of N0 cases. Most likely the increase of N0 patients in our group 2 (2000-2004) is related to the increased number of patients presenting with a lower T-stage at admission. In the Netherlands there is a clear decrease of the number of smokers after 1980. In $1980,43 \%$ of the population was smoking; in 2004 that number was $28 \%$. However, we have not noticed this decrease in our patient groups. In male as well as female patients no differences in smoking habits between the two groups was observed. In our study no statistically significant difference in smoking habits in women between the two periods was observed.

In the present study a significant decrease in the number of heavy drinkers between the two groups was observed; the percentages dropped from $32 \%$ in the 1980 1984 period to $18 \%$ in the $2000-2004$ period. In spite of less alcohol consumption and, in men, decreased smoking habits, one would expect to observe a decrease in the incidence of oral cancer, which is apparently not the case. No proper explanation can be provided for this observation $(2,3)$. 


\section{References}

1. Bray I, Brennan P, Boffetta P. Projections of alcohol- and tobaccorelated cancer mortality in Central Europe. Int J Cancer 2000; 87: $122-8$.

2. Gillison ML. Current topics in the epidemiology of oral cavity and oropharyngeal cancers. Head Neck 2007; 29: 779-92.

3. La Vecchia C, Lucchini F, Negri E, Levi F. Trends in oral cancer mortality in Europe. Oral Oncol 2004; 40: 433-9.

4. Syrjänen S, Lodi G, von Bultzingslowen I, et al. Human papillomaviruses in oral carcinoma and oral potentially malignant disorders: a systematic review. Oral Dis 2011; 17: 58-72.

5. Warnakulasuriya S. Global epidemiology of oral and oropharyngeal cancer. Oral Oncol 2009; 45: 309-16.

6. Karim-Kos HE, deVries E, Soerjomataram I, Lemmens V,Siesling S, Coebergh JW. Recent trends of cancer in Europe: a combined approach of incidence, survival and mortality for 17 cancer sites since the 1990s. Eur J Cancer 2008; 44: 1345-89.

7. Curado MP, Hashibe M. Recent changes in the epidemiology of head and neck cancer. Curr Opin Oncol 2009; 21: 194-200.

8. Chaturvedi AK, Engels EA, Anderson WF, Gillison ML. Incidence trends for human papillomavirus-related and -unrelated oral squamous cell carcinomas in the United States. J Clin Oncol 2008; 26: 612-9.

9. Bonifazi M, Malvezzi M, Bertuccio P, et al. Age-period-cohort analysis of oral cancer mortality in Europe: The end of an epidemic? Oral Oncol 2011; 47: 400-7.

10. Braakhuis BJ, Visser O, Leemans CR. Oral and oropharyngeal cancer in The Netherlands between 1989 and 2006: Increasing incidence, but not in young adults. Oral Oncol 2009; 45: e85-e89.

11. Muller S, Pan Y, Li R, Chi AC. Changing trends in oral squamous cell carcinoma with particular reference to young patients: 19712006. The Emory University experience. Head Neck Pathol 2008; 2: $60-6$.

12. Mackenzie J, Ah-See K, Thakker N, Sloan P, Maran AG, Birch J, Macfarlane GJ. Increasing incidence of oral cancer amongst young persons: what is aetiology. Oral Oncol 2000; 36: 387-9.

13. O'Regan EM, Timon C, Sheils O, Codd M, O’Leary JJ, Toner M. Squamous cell carcinoma of the head and neck in young Irish adults. Br J Oral Maxillofac Surg 2006; 44: 203-6.

14. Llewellyn CD, Linklater K, Bell J, Johnson NW, Warnakulasuriya $\mathrm{S}$. An analysis of risk factors for oral cancer in young people: a case-control study. Oral Oncol 2004; 40: 304-13.

15. Gorsky M, Epstein JB, Oakley C, Le ND, Hay J, StevensonMoore P. Carcinoma of the tongue: a case series analysis of clinical presentation, risk factors, staging, and outcome. Oral Surg Oral Med Oral Pathol Oral Radiol Endod 2004; 98: 546-52.

16. Lam L, Logan RM, Luke C. Epidemiological analysis of tongue cancer in South Australia for the 24-year period, 1977-2001. Aust Dent J 2006; 51: 16-22

17. Moore S, Johnson NW, Pierce AM, Wilson DF. The epidemiology of tongue cancer: a review of global incidence. Oral Dis 2000; 6: $75-84$.

18. Rusthoven K, Ballonoff A, Raben D, Chen C. Poor prognosis in patients with stage I and II oral tongue squamous cell carcinoma. Cancer 2008; 112: 345-51.

19. Brouha XDR, Tromp DM, De Leeuw JRJ, Koole R, Slootweg PJ, Hordijk GJ. Stijgende incidentie van invasieve (T4)-hoofd-halscarcinomen in het Universitair Medisch Centrum Utrecht, 1980-1998. Nederl Tijdschr Geneeskd 2002; 146: 1131-5.

20. Hoffman H, Karnell LH, Funk GF, Robinson RA, Menck HR. The National Cancer Data Base report on cancer of the head and neck. Arch Otolaryngol Head Neck Surg 1998; 124: 951-62.

\section{Acknowledgement}

We thank dr. Sylvia Francesci from the department of Epidemiology and Biological Statistics, UICC, Lyon, France for her valuable comments on the manuscript. 